\title{
PENGARUH STRATEGI NAFKAH TERHADAP DINAMIKA KEMISKINAN DI WILAYAH HULU DAN HILIR SUNGAI CIMANUK, JAWA BARAT
}

\author{
Hurriyyatun Kabbaro $\left.{ }^{1 *}\right)$, Hartoyo ${ }^{2}$, Lilik Noor Yuliati ${ }^{2}$ \\ ${ }_{1}^{1}$ Program Studi IImu Keluarga dan Perkembangan Anak, Sekolah Pascasarjana, Institut Pertanian Bogor, Bogor \\ 16680, Indonesia \\ ${ }^{2}$ Departemen Ilmu Keluarga dan Konsumen, Fakultas Ekologi Manusia, Institut Pertanian Bogor, Bogor 16680, \\ Indonesia \\ *)Email: hurriyyatun.kabbaro@gmail.com
}

\begin{abstract}
Abstrak
Penelitian ini bertujuan menganalisis pengaruh strategi nafkah terhadap dinamika kemiskinan di wilayah hulu dan hilir Sungai Cimanuk, Jawa Barat. Penelitian menggunakan desain cross-sectional dan kajian historical. Kabupaten Garut di wilayah hulu dan Kabupaten Indramayu di wilayah hilir dipilih secara sengaja sebagai lokasi penelitian. Penelitian melibatkan 138 keluarga yang memiliki anak balita dan sekolah di wilayah hulu dan hilir Sungai Cimanuk. Pengambilan data dilakukan melalui wawancara menggunakan kuesioner dengan pemilihan contoh secara sengaja berdasarkan kriteria penelitian. Regresi multinomial logistik digunakan untuk menemukan faktor yang memengaruhi status dinamika kemiskinan. Hasil penelitian menunjukkan bahwa kemiskinan di wilayah hulu didominasi oleh kelompok jatuh miskin sedangkan di wilayah hilir didominasi oleh kelompok selalu miskin. Keluarga di wilayah hilir memiliki kemungkinan keluar dari kemiskinan yang lebih tinggi dibandingkan keluarga di wilayah hulu. Analisis regresi multinomial menunjukkan bahwa strategi nafkah berpengaruh terhadap dinamika kemiskinan. Investasi modal manusia melalui pendidikan formal dan penguatan pola nafkah berbasis potensi lokal perlu digalakan untuk mengurangi kemiskinan.
\end{abstract}

Kata kunci: daerah aliran sungai (DAS), dinamika kemiskinan, historical study, stategi nafkah

\section{The Effect of Livelihood Stategy towards Poverty Dynamics in Upstream and Downstream Region of Cimanuk Watershed, West Java}

\begin{abstract}
This study examined the effect of livelihood strategy on poverty dynamics in upstream and downstream region of Cimanuk Watershed, West Java. Study used cross-sectional and historical design. Study was conducted in Garut Disctict as upstream region and Indramayu District as downstream region. This research involved 138 families who have preschool and school child. The families were chosen by purposive sampling and the data was obtained by interview using questionnaire. Multinomial logistic regression was used to find factors influencing poverty dynamics status. The result showed that poverty in upstream region was dominated by moving into poverty dynamic, whereas poverty in downstream region was dominated by always poor dynamic. Families in downstream region have higher possibility to moving out of poverty than families in upstream region. Multinomial regression analysis showed that livelihood strategy had influence on poverty dynamics. Human capital investment in formal education and strengthening local-based livelihood patterns should be encouraged to reduce poverty.
\end{abstract}

Keywords:poverty dinamics, historical study, livelihood stategy, watershed

\section{PENDAHULUAN}

Kajian-kajian mengenai dinamika kemiskinan umumnya menekankan pada peran keluarga generasi awal dalam transfer kemiskinan antargenerasi, khususnya melalui investasi orang tua terhadap anak (Becker, 1993; Hartoyo, Herawati \& Djamaluddin, 2013; Surachman \& Hartoyo, 2015). Hal ini dilandasi oleh teori Gary Becker yang berpendapat bahwa sumber daya manusia atau pendidikan merupakan faktor kuat yang memengaruhi kemiskinan (Magnuson \& Vortubra, 2009). Berdasarkan kajian ini, Indonesia telah tanggap mengembangkan dan menerapkan kebijakan pengentasan kemiskinan melalui program beasiswa pendidikan tinggi untuk keluarga miskin yang dimulai sejak tahun 2010. Berbagai kebijakan kemiskinan lainnya terus diterapkan untuk menurunkan angka kemiskinan, seperti Bantuan Langsung Tunai, Program Keluarga Harapan, Beras Miskin, Jaminan Kesehatan Masyarakat, Bantuan Tunai bagi Siswa Miskin (BSM). Akan tetapi, 
program pengentasan kemiskinan yang dilakukan di Indonesia nampaknya belum berhasil menurunkan angka kemiskinan secara signifikan. Badan Pusat Statistik (2015) mencatat pada tahun 2015 angka kemiskinan Indonesia meningkat menjadi 11,56 persen, sedangkan pada tahun sebelumnya mencapai 10,56 persen. Fakta ini juga menunjukkan bahwa Indonesia telah gagal dalam mencapai target pengentasan kemiskinan berdasarkan MDG's sebesar 7,5 persen pada tahun 2015. Sulitnya menurunkan angka kemiskinan mengindikasikan adanya kemiskinan kronis yang menjebak keluarga. Hal ini terbukti melalui penelitian Simanjuntak et al. (2013), yakni tidak adanya perubahan status kemiskinan yang signifikan pada keluarga penerima Program Keluarga Harapan. Bank Dunia menganalisis ketidakefektifan program pengentasan kemiskinan di Indonesia akibat ketidaktepatan sasaran penerima bantuan. Hal ini didukung oleh penelitian Puspitawati(2008), yakni sekitar setengah dari jumlah rumah tangga miskin dinyatakan salah sasaran pada program SLT-BBM.

Pengentasan kemiskinan akan lambat jika kebijakan tidak diarahkan pada kemandirian keluarga melalui kesejahteraan nafkah. Kerangka kerja strategi nafkah berkelanjutan (sustainable livelihood approach) yang dikembangkan Scoones (1998) melihat proses dinamika kemiskinan/kesejahteraan individu melalui pemanfaatan sumberdaya, keterbukaan akses, dan strategi nafkah. Strategi nafkah merupakan mekanisme yang dilakukan individu atau kelompok (rumah tangga) untuk bertahan hidup melalui proses manipulasi sosio ekonomi atas berbagai sumber penghidupan (Dharmawan, 2007). Sumber daya, akses, pengaruh, dan strategi nafkah berpengaruh terhadap perubahan kesejahteraan (Morse \& McNamara, 2013; Scoones, 2009). Kajian dinamika kemiskinan menggunakan pendekatan strategi nafkah berkelanjutan sangat menarik dikaji karena memiliki konsep yang komprehensif mengingat pendekatan ini tidak hanya mengkaji sumber daya yang ada.

Penelitian ini mengkaji dinamika kemiskinan di wilayah hulu dan hilir Sungai Cimanuk. Daerah Aliran Sungai Cimanuk (DAS Cimanuk) merupakan wilayah kritis yang rawan bencana (KLH, 2012). Kondisi ini mendorong kerentanan aktivitas nafkah dan kerentanan ekonomi keluarga. Berdasarkan karakteristik sosial ekonomi di DAS Cimanuk, Kabupaten Garut sebagai wilayah hulu juga termasuk ke dalam wilayah yang memiliki penduduk miskin terbanyak di Jawa Barat. Sementara itu, Kabupaten Indramayu yang merupakan wilayah hilir DAS juga termasuk ke dalam wilayah yang memiliki IPM terendah di Jawa Barat. Pengkajian dua wilayah dilakukan untuk melihat perbedaan pola dinamika kemiskinan di dua wilayah DAS Cimanuk dengan karakteristik berbeda. Berdasarkan penelitian Hartoyo et al. (2013), penting melakukan kajian kemiskinan berdasarkan wilayah karena karakteristik setiap wilayah berbeda. Secara umum, penelitian ini bertujuan menganalisis pengaruh strategi nafkah terhadap dinamika kemiskinan di wilayah hulu dan hilir Sungai Cimanuk. Secara khusus, kajian ini akan mengarah pada analisis pola dinamika kemiskinan dan strategi nafkah di kedua wilayah dan pengaruh strategi nafkah dalam menentukan dinamika kemiskinan.

\section{METODE}

Penelitian ini menggunakan desain crosssectional dan kajian historical. Lokasi penelitian dipilih secara sengaja, yakni di hulu dan hilir Daerah Aliran Sungai (DAS) Cimanuk. Wilayah Hulu berada di Kabupaten Garut, sedangkan wilayah hilir berada di Kabupaten Indramayu.

Contoh dalam penelitian ini adalah 138 keluarga yang dianggap sebagai generasi II yang mempunyai anak balita dan usia sekolah serta bertempat tinggal di wilayah hulu (Kabupaten Garut) dan hilir (Kabupaten Indramayu) DAS Cimanuk. Unit analisis dalam penelitian ini adalah keluarga generasi II. Data dibagi kedalam dua kategori, yaitu 69 keluarga mewakili wilayah hulu (Kabupaten Garut) dan 69 keluarga mewakili wilayah hilir (Kabupaten Indramayu). Pada setiap wilayah, contoh digolongkan menjadi dua karakteristik berdasarkan status kesejahteraan, yaitu keluarga miskin dan keluarga tidak miskin. Data di wilayah hulu terdiri atas 30 keluarga miskin dan 39 keluarga tidak miskin. Data di wilayah hilir terdiri atas 33 keluarga miskin dan 36 keluarga tidak miskin.

Jenis data yang dikumpulkan meliputi data primer. Pengumpulan data primer dilakukan melalui wawancara menggunakan kuesioner pada keluarga generasi II (suami dan isteri). Data terkait generasi I diperoleh dengan mewawancarai keluarga generasi II dengan metode mengingat kembali (recall). Tingkat kesejahteraan keluarga generasi I diukur dengan menggunakan instrumen Family Life History (FLH) yang dikembangkan oleh Bottema, Siregar, dan Madiadipura (2009). 
Indikator yang digunakan meliputi stabilitas pendapatan keluarga, kepemilikan dan kondisi rumah, kepemilikan aset (lahan pertanian dan hewan ternak), kemampuan literasi orang tua, dan pengaruh orang tua di masyarakat. Kategori jawaban menggunakan skala Guttman, yakni "skor 1=ya" dan "skor 0=tidak". Status kemiskinan keluarga generasi I ditentukan dari total skor FLH, yakni "total skor $>5=$ tidak miskin" dan "total skor <5=miskin". Batas skor ditentukan berdasarkan penyetaraan kategori miskin BKKBN berdasarkan indikator penerima BLT.

Tingkat kesejahteraan keluarga generasi II diukur berdasarkan garis kemiskinan kabupaten/kota 2013. Garis kemiskinan (GK) Indramayu adalah Rp350.455 sedangkan garis kemiskinan Garut adalah Rp226.308. Status kemiskinan keluarga generasi II ditentukan dari garis kemiskinan, yakni "pengeluaran $>1.5 x G K=$ tidak miskin" dan "pengeluaran $<1,5 x G K=$ miskin". Penentuan 1,5 GK mengacu pada analisis kemiskinan Susenas (Bank Dunia, 2013) dan bertujuan menajamkan perencanaan makro, yakni menggolongkan masyarakat yang rentan miskin menjadi masyarakat miskin. Analisis dinamika kemiskinan digolongkan pada empat kategori, yakni:

- Selalu miskin jika generasi I dan generasi II keluarga selalu berada dalam kondisi miskin.

- Jatuh miskin jika keluarga generasi I tidak miskin namun keluarga generasi II miskin.

- Keluar dari kemiskinan jika keluarga generasi I miskin namun keluarga generasi II tidak miskin.

- Tidak pernah miskin jika generasi I dan generasi II keluarga tidak pernah miskin.

Pengukuran variabel strategi nafkah memodifikasi kuesioner yang dikembangkan oleh Scoones (1998). Realibilitas instrumen telah diuji dengan Cronbach's alpha sebesar 0,620 . Dimensi strategi nafkah diantaranya rekayasa sumber nafkah, nafkah ganda, dan rekayasa spasial. Kategori jawaban menggunakan empat tingkatan, yaitu skor 1 untuk 'tidak pernah', skor 2 untuk 'kadangkadang', skor 3 untuk 'sering', skor 4 untuk 'sangat sering'. Instrumen terdiri atas 12 butir pertanyaan dengan skor minimal 12 dan skor maksimal 48. Setelah itu, jumlah skor dikonversi ke dalam indeks 0-100 dan dibagi pada tiga kategori, yaitu rendah $(0,0-60,0)$, sedang $(60,0-79,9)$, dan tinggi $(80,0-100,0)$.
Data diolah menggunakan program Microsoft Excel dan Statistical Package for Social Science (SPSS). Analisis deskriptif digunakan untuk mengukur rata-rata, nilai minimum dan maksimum, tabulasi silang dan presentase. Uji regresi logistik multinomial digunakan untuk melihat faktor-faktor yang memengaruhi dinamika kemiskinan. Kategori referensi yang digunakan adalah kelompok tidak pernah miskin. Interpretasi model menggunakan interpretasi nilai $\operatorname{Exp}(B)$ sesuai kaidah statistik.

\section{HASIL}

\section{Karakteristik Keluarga Generasi I}

Hasil penelitian menunjukkan bahwa hampir seluruh orang tua suami dan istri di wilayah hulu dan hilir memiliki pendapatan yang tidak stabil. Keluarga generasi I memiliki rata-rata jumlah anak yang lebih besar dibandingkan dengan keluarga generasi II. Orang tua suami dan istri yang tidak miskin di wilayah hulu lebih banyak yang memiliki lahan pertanian dan hewan ternak dibandingkan orang tua dari suami dan istri yang miskin. Orang tua di wilayah hulu lebih banyak yang memiliki pengaruh di masyarakat dibandingkan di wilayah hilir.

\section{Karakteristik Keluarga Generasi II}

Hasil penelitian menunjukkan bahwa keluarga generasi II yang tidak miskin memiliki rata-rata besar keluarga yang lebih sedikit dibandingkan keluarga miskin di wilayah hulu dan hilir. Berdasarkan strata pendidikan, enam dari sepuluh suami dan istri di wilayah hulu hanya menamatkan pendidikan pada tingkat sekolah dasar. Sementara di wilayah hilir, lima dari sepuluh suami dan istri telah menamatkan wajib pendidikan sembilan tahun. Suami dan istri dari keluarga tidak miskin lebih banyak yang telah menamatkan jenjang pendidikan SMP dibandingkan dari keluarga miskin di wilayah hulu dan hilir.

Hasil penelitian menunjukkan bahwa lima dari sepuluh suami di wilayah hulu dan lima dari sepuluh suami di wilayah hilir bekerja sebagai buruh. Hasil uji beda menunjukkan bahwa terdapat perbedaan yang nyata dan signifikan pada pengeluaran per kapita antara keluarga miskin dan tidak miskin di wilayah hulu dan hilir. Keluarga tidak miskin memiliki rata-rata pengeluaran per kapita yang lebih besar dibandingkan keluarga miskin di kedua wilayah. Keluarga miskin di wilayah hulu memiliki pengeluaran pangan yang lebih besar dibandingkan pengeluaran nonpangan. 
Sementara pada keluarga tidak miskin di kedua wilayah memiliki pengeluaran nonpangan yang lebih besar dibandingkan pengeluaran pangan keluarga.

\section{Strategi Nafkah}

Strategi nafkah pada penelitian ini dikaji berdasarkan tiga dimensi, yaitu rekayasa sumber nafkah, nafkah ganda, dan rekayasa spasial. Rata-rata skor indeks strategi nafkah secara agregat di wilayah hulu $(24,92)$ dan hilir $(23,67)$ DAS Cimanuk masih tergolong rendah (Gambar 1). Kajian uji beda strategi nafkah antarwilayah menunjukkan bahwa terdapat perbedaan yang nyata antara keluarga di wilayah hulu dengan keluarga di wilayah hilir dalam melakukan strategi rekayasa sumber nafkah $(p<0,05)$ dan rekayasa spasial $(p<0,01)$. Akan tetapi, tidak ditemukan adanya perbedaan yang nyata antara keluarga di wilayah hulu dengan keluarga di wilayah hilir dalam melakukan strategi rekayasa spasial. Berdasarkan status miskin, strategi nafkah yang dimiliki oleh keluarga miskin (ratarata $=17,04$ ) lebih sedikit dibandingkan keluarga tidak miskin (rata-rata $=30,98$ ) di wilayah hulu. Akan tetapi, strategi nafkah yang dimiliki oleh keluarga miskin di wilayah hilir (rata-rata $=25,76$ ) lebih banyak dibandingkan keluarga tidak miskin (rata-rata=21,76).

Strategi rekayasa sumber nafkah. Strategi rekayasa sumber nafkah dilakukan keluarga dengan meragamkan satu sumber nafkah utama (misalkan menanam dengan teknik tumpang sari), meminjam modal usaha, memperluas lahan/usaha untuk dijadikan sumber pendapatan, menambah tenaga kerja, dan menggunakan teknologi untuk memaksimalkan output kerja. Strategi rekayasa sumber nafkah yang sangat sering digunakan oleh keluarga di wilayah hulu adalah meragamkan sumber nafkah utama (dilakukan oleh 26,7\% keluarga miskin dan
46,2\% keluarga tidak miskin). Temuan ini didukung oleh fakta jenis pekerjaan sebagian besar keluarga di wilayah hulu adalah sebagai petani dan buruh tani. Sementara itu, di wilayah hilir, strategi rekayasa sumber nafkah yang sangat sering digunakan keluarga adalah meminjam modal usaha (dilakukan oleh $27,3 \%$ keluarga miskin dan $25,0 \%$ keluarga tidak miskin). Temuan lain juga menunjukkan lebih dari seperempat suami di wilayah hilir $(27,5 \%)$ berprofesi sebagai wiraswasta (baik dari skala kecil maupun besar).

Strategi nafkah ganda. Pada penelitian ini, strategi nafkah ganda dilakukan oleh keluarga dengan suami memiliki pekerjaan lebih dari satu; anggota keluarga (istri/anak) tetap bekerja meskipun suami memiliki penghasilan tetap; atau anggota keluarga (istri/anak) memiliki pekerjaan lebih dari satu. Hasil penelitian menunjukkan bahwa strategi nafkah ganda yang sangat sering dilakukan oleh keluarga di wilayah hulu dan hilir adalah anggota keluarga (istri/anak) tetap bekerja meskipun suami memiliki penghasilan tetap. Hasil temuan ini mengindikasikan bahwa lebih dari seperempat keluarga miskin $(26,7 \%)$ dan tidak miskin $(33,3 \%)$ di wilayah hulu memiliki pencari nafkah lebih dari satu (suami dan istri/anak). Sementara itu, hasil yang sama dapat dilihat pada tiga dari sepuluh keluarga miskin (33,3\%) dan tidak miskin $(30,6 \%)$ di wilayah hilir.

Strategi rekayasa spasial. Strategi rekayasa spasial yang dilakukan oleh keluarga adalah dengan bermigrasi 'sendiri atau dengan seluruh keluarga' secara 'permanen atau sementara' ke daerah lain karena tidak terdapat pilihan pekerjaan di daerah asal. Hasil penelitian di wilayah hulu menunjukkan bahwa strategi rekayasa spasial yang sangat sering dilakukan oleh keluarga miskin adalah bekerjanya istri/anak di luar wilayah domisili $(6,7 \%)$.

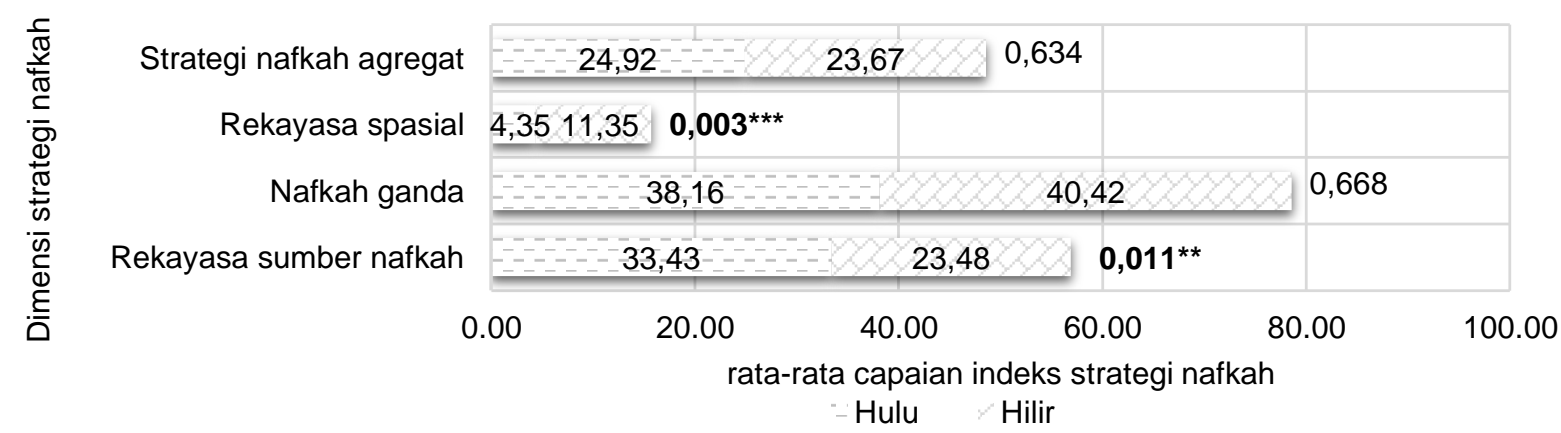

Gambar 1 Grafik uji beda strategi nafkah antarwilayah pada keluarga generasi II 
Sementara itu, keluarga tidak miskin di wilayah hulu sangat sering melakukan strategi rekayasa spasial dengan migrasi seluruh anggota keluarga secara permanen ke daerah sumber nafkah (2,6\%) dan terdapatnya istri/anak yang bekerja di luar wilayah domisili $(2,6 \%)$. Kajian strategi rekayasa spasial di wilayah hilir pada kategori sering dan sangat sering menunjukkan bahwa 18,2 persen keluarga miskin dan 11,2 persen keluarga tidak miskin memiliki anggota keluarga yang bekerja sebagai TKI untuk memperoleh pendapatan keluarga. Sementara itu, 15,2 persen keluarga miskin dan 22,2 persen keluarga tidak miskin di wilayah hilir memiliki suami yang bekerja di luar domisili keluarga. Hasil penelitian ini mengindikasikan mobilitas nafkah pada keluarga di wilayah hilir lebih tinggi dibandingkan keluarga di wilayah hulu.

Dinamika kemiskinan. Dinamika kemiskinan merupakan perubahan status kemiskinan yang dialami individu dari masa kanak-kanak hingga masa dewasa. Hasil penelitian menunjukkan bahwa lebih dari separuh keluarga miskin di wilayah hulu, baik suami maupun istri, berasal dari keluarga yang berstatus tidak miskin. Hal ini menunjukkan sebagian besar keluarga miskin di wilayah hulu banyak yang mengalami jatuh miskin setelah membentuk keluarga di generasi berikutnya. Hasil yang berbeda ditemukan di wilayah hilir, yakni lebih dari separuh keluarga miskin di wilayah hilir, baik suami dan istri, berasal dari keluarga dengan status miskin juga. Hal ini menunjukkan sebagian besar keluarga miskin di wilayah hilir mengalami kemiskinan kronis. Hasil penelitian menunjukkan bahwa 47,22 persen suami dan 61,11 persen istri pada keluarga tidak miskin di wilayah hilir berhasil keluar dari kemiskinan keluarga asal. Temuan juga menunjukkan bahwa lebih dari separuh suami dari keluarga tidak miskin di wilayah hilir berasal dari keluarga yang tidak miskin juga. Dinamika kemiskinan keluarga tersaji pada Gambar 2.

Kelompok selalu miskin. Dinamika selalu miskin menunjukkan adanya kemiskinan kronis pada individu. Pada penelitian ini, kondisi selalu miskin merupakan kondisi individu (suami/istri) yang mengalami status miskin pada masa kanak-kanak dan masa dewasa. Pendapatan per kapita keluarga yang selalu miskin berada di bawah garis kemiskinan Bank Dunia US\$2 per hari (Purchasing Power Parity dalam rupiah senilai $\mathrm{Rp} 12.480)$, baik di wilayah hulu (Rp7.480) maupun hilir (Rp9.900). Hasil menunjukkan bahwa lebih dari separuh suami yang selalu miskin di wilayah hulu $(63,6 \%)$ dan di wilayah hilir $(52,4 \%)$ bekerja sebagai buruh nontani. Sementara itu, dua dari sepuluh suami yang selalu miskin di kedua wilayah bekerja sebagai buruh tani. Berdasarkan capaian pendidikan, tujuh dari sepuluh suami yang selalu miskin berpendidikan tamat SD.

Hasil penelitian menunjukkan bahwa suami dan istri di wilayah hilir memiliki peluang selalu miskin yang lebih besar dibandingkan suami dan istri di wilayah hulu. Hal ini dapat terjadi akibat perbedaan biaya hidup. Rata-rata pengeluaran per kapita keluarga di wilayah hilir (Rp384.000) lebih besar dibandingkan di wilayah hulu (Rp253.000). Rendahnya tingkat pendidikan, jenis pekerjaan dengan penghasilan rendah, pendapatan tidak stabil, dan biaya hidup yang tinggi membuat keluarga sulit keluar dari kemiskinan.

\begin{tabular}{|c|c|}
\hline $\begin{array}{c}17,39 \% \\
\text { Keluar dari } \\
\text { Kemiskinan }\end{array}$ & $\begin{array}{c}39,13 \% \\
\text { Tidak Pernah } \\
\text { Miskin }\end{array}$ \\
\hline $15,94 \%$ & $27,54 \%$ \\
Selalu & Jatuh \\
Miskin & Miskin \\
\hline \multicolumn{2}{|c|}{ Dinamika Kemiskinan Suami di Wilavah Hulu } \\
\hline
\end{tabular}

\begin{tabular}{|c|c|}
\hline $\begin{array}{c}24,64 \% \\
\text { Keluar dari } \\
\text { Kemiskinan }\end{array}$ & $\begin{array}{c}27,54 \% \\
\text { Tidak Pernah } \\
\text { Miskin }\end{array}$ \\
\hline $30,43 \%$ & $17,39 \%$ \\
Selalu & Jatuh \\
Miskin & Miskin \\
\hline \multicolumn{2}{|c|}{ Dinamika Kemiskinan Suami di Wilavah Hilir } \\
\hline
\end{tabular}

\begin{tabular}{|c|c|}
\hline $\begin{array}{c}8,70 \% \\
\text { Keluar dari } \\
\text { Kemiskinan }\end{array}$ & $\begin{array}{c}47,83 \% \\
\text { Tidak Pernah } \\
\text { Miskin }\end{array}$ \\
\hline $20,29 \%$ & $\begin{array}{c}23,19 \% \\
\text { Jelalu } \\
\text { Miskin }\end{array}$ \\
\hline Miskin \\
\hline \multicolumn{2}{|c|}{ Dinamika Kemiskinan Istri di Wilayah Hulu } \\
\hline
\end{tabular}

\begin{tabular}{|c|c|}
\hline $\begin{array}{c}31,88 \% \\
\text { Keluar dari } \\
\text { Kemiskinan }\end{array}$ & $\begin{array}{c}20,29 \% \\
\text { Tidak Pernah } \\
\text { Miskin }\end{array}$ \\
\hline $39,13 \%$ & $8,70 \%$ \\
Selalu & Jatuh \\
Miskin & Miskin \\
\hline Dinamika Kemiskinan Istri di Wilayah Hilir \\
\hline
\end{tabular}

Gambar 2 Status dinamika kemiskinan di wilayah hulu dan hilir DAS Cimanuk 
Kelompok jatuh miskin. Dinamika jatuh miskin menunjukkan adanya mobilitas ke bawah (downward mobility). Hasil penelitian menunjukkan bahwa suami dan istri di wilayah hulu memiliki peluang jatuh miskin yang lebih besar dibandingkan dengan suami dan istri di wilayah hilir. Keragaman jenis pekerjaan di wilayah hulu cenderung rendah. Keluarga di wilayah hulu sangat mengandalkan sektor pertanian untuk bertahan hidup. Ketika keluarga menghadapi krisis ekonomi, keluarga menambah pendapatan dengan bekerja di lahan orang lain sebagai buruh tani. Pada kondisi krisis ekonomi, keluarga cenderung hidup secukupnya (mengurangi pengeluaran). Keluarga memanfaatkan alam dan hasil tani untuk kebutuhan pangan keluarga. Rendahnya pendidikan dan kepemilikan modal nonalam membatasi akses pengembangan strategi nafkah keluarga.

Pendapatan yang diperoleh dari pekerjaan mereka cenderung digunakan hanya untuk bertahan hidup. Peningkatan kesejahteraan cukup sulit dilakukan karena rendahnya pendapatan yang diperoleh. Rata-rata pendapatan per kapita yang diperoleh keluarga di wilayah hulu sebesar Rp10.493 per hari. Kondisi pendapatan ini bersifat tidak stabil. Pendapatan dari hasil pertanian sangat tergantung pada iklim, kuantitas dan kualitas hasil panen, serta harga jual di tengkulak. Ketidakstabilan pendapatan, rendahnya pendidikan, sedikitnya alternatif nafkah, dan terbatasnya akses mendorong keluarga di wilayah hulu rentan untuk jatuh miskin.

Kelompok keluar dari kemiskinan. Dinamika keluar dari kemiskinan menunjukkan adanya mobilitas ke atas (upward mobility). Hasil penelitian menunjukkan bahwa suami dan istri di wilayah hilir memiliki peluang keluar dari kemiskinan yang lebih besar dibandingkan dengan suami dan istri di wilayah hulu. Karakteristik pendidikan yang lebih tinggi dan akses yang lebih terbuka di wilayah hilir membuat individu memiliki lebih banyak pilihan jenis pekerjaan. Keluarga yang menghadapi kondisi krisis di wilayah hilir dapat lebih mudah bermigrasi (sementara/permanen) ke kota lain untuk memperoleh pekerjaan. Jarak, waktu tempuh, biaya, dan transportasi dari wilayah hilir relatif terjangkau. Kondisi ini mendorong keluarga di wilayah hilir untuk memiliki mobilitas yang lebih tinggi dibandingkan di wilayah hulu. Wilayah hilir juga memiliki banyak agen buruh migran Indonesia (TKI). Agen TKI ini membuka alternatif sumber pekerjaan bagi keluarga di wilayah hilir. Bagi
TKI yang cerdik dan mendapatkan majikan yang baik, dapat melanjutkan pendidikannya di luar negeri. Sebagian kecil kasus, TKI dapat memanfaatkan peluang dengan baik, pulang ke tanah air dengan pendidikan yang lebih tinggi, finansial yang lebih baik, serta memperoleh pekerjaan dan pendapatan yang lebih stabil di tanah air. Akan tetapi, ketidakberuntungan kondisi (majikan yang keras, tempat, dan jenis pekerjaan) bekerja sebagai TKI memiliki resiko yang tinggi terhadap kesejahteraan individu.

Kelompok tidak pernah miskin. Hasil penelitian menunjukkan bahwa suami dan istri di hulu memiliki peluang tidak pernah miskin lebih besar dibandingkan dengan keluarga di hilir. Berdasarkan pekerjaan, empat dari sepuluh suami yang tidak pernah miskin di wilayah hulu bekerja sebagai petani. Sebagian petani di wilayah hulu berprofesi ganda sebagai tengkulak. Tengkulak memiliki andil dalam menentukan harga jual hasil panen sehingga keuntungan yang diperoleh lebih besar. Selain itu, biaya hidup di hulu lebih rendah dibandingkan dengan di wilayah hilir. Keluarga di wilayah hulu pada umumnya hidup secukupnya. Keluarga juga memanfaatkan hasil panen sebagai bahan pangan keluarga. Kepemilikan lahan pertanian dan ketersediaan penyewaan lahan Perhutani menjadi tumpuan nafkah keluarga di wilayah hulu.

\section{Faktor-Faktor yang Memengaruhi Dinamika Kemiskinan}

Model umum. Analisis regresi logistik multinomial pada dinamika kemiskinan suami menunjukkan bahwa model yang disusun dalam penelitian terbentuk signifikan (ChiSquare $=156,977 ; \quad p<0,001)$. Model dapat menjelaskan 72,60 persen faktor-faktor yang memengaruhi dinamika kemiskinan suami, dan sisanya dipengaruhi oleh variabel lain yang tidak diteliti. Analisis regresi logistik multinomial pada dinamika kemiskinan istri juga menunjukkan bahwa model yang disusun dalam penelitian terbentuk signifikan (ChiSquare $=195,156 ; \quad p<0,001)$. Model dapat menjelaskan 81,20 persen faktor-faktor yang memengaruhi dinamika kemiskinan istri, dan sisanya dipengaruhi oleh variabel lain yang tidak diteliti (Tabel 1). Dalam model yang dibangun, dilakukan tiga dummy pada variabel y dengan membedakan makna pada nilai 1 . Ketiga model yang dibangun, nilai 1 berturutturut bermakna bahwa keluarga di wilayah aliran sungan Cimanuk selalu miskin, jatuh miskin, dan keluar dari kemiskinan. 
Tabel 1 Faktor-faktor yang memengaruhi dinamika kemiskinan suami dan istri

\begin{tabular}{|c|c|c|c|c|}
\hline \multirow[t]{3}{*}{ Variabel Independen } & \multicolumn{4}{|c|}{$\begin{array}{c}\text { Dinamika Kemiskinan (1=selalu miskin, } 2=\text { jatuh } \\
\text { miskin, 3=keluar dari kemiskinan, 4=tidak pernah } \\
\text { miskin) }\end{array}$} \\
\hline & \multicolumn{2}{|c|}{ Suami } & \multicolumn{2}{|c|}{ Istri } \\
\hline & $\mathrm{B}$ & $\operatorname{Exp}(B)$ & $\mathrm{B}$ & $\operatorname{Exp}(\mathrm{B})$ \\
\hline \multicolumn{5}{|l|}{ Tidak pernah miskin (0) vs selalu miskin (1) } \\
\hline Intercept & $-22,095$ & & $-7,268$ & \\
\hline \multicolumn{5}{|l|}{ Keluarga generasi I } \\
\hline Besar keluarga & 0,039 & 1,040 & 0,045 & 1,046 \\
\hline Pendidikan ibu ( $0=$ tidak bisa calistung; 1 =bisa calistung) & 20,458 & $7,669 \times 10^{8}$ & 4,911 & $135,757^{* * *}$ \\
\hline Kepemilikan lahan pertanian ( $0=$ tidak punya; $1=$ punya) & 19,045 & $1,867 \times 10^{8}$ & 7,287 & $1,462 \times 10^{3 * \star *}$ \\
\hline Pengaruh di masyarakat ( $0=$ tidak punya; $1=$ punya) & 4,777 & $118,758^{\star * *}$ & 4,301 & $73,751^{* * *}$ \\
\hline \multicolumn{5}{|l|}{ Keluarga generasi II } \\
\hline Besar keluarga & 0,474 & 1,606 & 0,230 & 1,259 \\
\hline Pendidikan anak (suami/istri) & $-0,319$ & $0,727^{\star *}$ & $-0,312$ & $0,732^{* *}$ \\
\hline \multicolumn{5}{|l|}{ Strategi nafkah keluarga } \\
\hline - Strategi rekayasa sumber nafkah & $-0,042$ & $0,959^{*}$ & $-0,023$ & 0,977 \\
\hline - Strategi nafkah ganda & 0,007 & 1,007 & $-0,011$ & 0,989 \\
\hline - Strategi rekayasa spasial & 0,008 & 1,008 & 0,011 & 1,011 \\
\hline \multicolumn{5}{|l|}{ Tidak pernah miskin (0) vs jatuh miskin (1) } \\
\hline Intercept & $-2,508$ & & $-2,186$ & \\
\hline \multicolumn{5}{|l|}{ Keluarga generasi I } \\
\hline Besar keluarga & 0,066 & 1,068 & 0,211 & 1,234 \\
\hline Pendidikan ibu ( $0=$ tidak bisa calistung; $1=$ bisa calistung) & $-15,867$ & $1,285 \times 10^{7}$ & $-20,552$ & $1,187 \times 10^{-9}$ \\
\hline Kepemilikan lahan pertanian $(0=$ tidak pur & 0,286 & 1,331 & 1,055 & 2,871 \\
\hline Pengaruh di masyarakat $(0=$ tidak punya; $1=$ punya $)$ & 0,597 & 1,816 & $-0,697$ & 0,498 \\
\hline \multicolumn{5}{|l|}{ Keluarga generasi II } \\
\hline Besar keluarga & 0,491 & $1,634^{\star *}$ & 0,608 & $1,837^{* *}$ \\
\hline Pendidikan anak (suami/istri) & $-0,057$ & 0,945 & $-0,259$ & $0,771^{*}$ \\
\hline \multicolumn{5}{|l|}{ Strategi nafkah keluarga } \\
\hline - Strategi rekayasa sumber nafkah & $-0,037$ & $0,964^{* *}$ & $-0,035$ & $0,965^{*}$ \\
\hline - Strategi nafkah ganda & 0,006 & 1,006 & $-0,008$ & 0,992 \\
\hline - Strategi rekayasa spasial & 0,007 & 1,007 & 0,044 & 1,045 \\
\hline \multicolumn{5}{|l|}{ Tidak pernah miskin (0) vs keluar dari kemiskinan (1) } \\
\hline Intercept & $-35,817$ & & $-2,853$ & \\
\hline \multicolumn{5}{|l|}{ Keluarga generasi I } \\
\hline Besar keluarga & 0,140 & 1,150 & $-0,058$ & 0,944 \\
\hline Pendidikan ibu (0=tidak bisa calistung; 1 =bisa calistung) & 19,873 & $4,275 \times 10^{8}$ & 5,141 & $170,915^{\star \star *}$ \\
\hline Kepemilikan lahan pertanian ( $0=$ tidak punya; $1=$ punya) & 34,775 & $1,267 \times 10^{15}$ & 5,391 & $219,358^{* * *}$ \\
\hline Pengaruh di masyarakat $(0=$ tidak punya; $1=$ punya $)$ & 3,769 & $43,330^{* * *}$ & 2,291 & $9,887^{* *}$ \\
\hline \multicolumn{5}{|l|}{ Keluarga generasi II } \\
\hline Besar keluarga & $-0,295$ & 0,745 & $-0,166$ & 0,847 \\
\hline Pendidikan anak (suami/istri) & $-0,108$ & 0,898 & $-0,114$ & 0,893 \\
\hline \multicolumn{5}{|l|}{ Strategi nafkah keluarga } \\
\hline - Strategi rekayasa sumber nafkah & $-0,018$ & 0,982 & $-0,011$ & 0,989 \\
\hline - Strategi nafkah ganda & 0,003 & 1,003 & $-0,032$ & $0,969^{\star *}$ \\
\hline - Strategi rekayasa spasial & 0,017 & 1,017 & 0,037 & 1,038 \\
\hline Chi-square & & 6,977 & & 95,156 \\
\hline Negekerke R-Square & & 0,726 & & 0,812 \\
\hline Signifikansi & & $0,000^{\star \star *}$ & & $0,000^{\star \star \star}$ \\
\hline
\end{tabular}

Tidak pernah miskin vs selalu miskin. Hasil penelitian menunjukkan bahwa faktor pada keluarga generasi I yang berpengaruh terhadap dinamika kemiskinan suami adalah pengaruh orang tua di masyarakat $(\alpha<0,01)$. Orang tua yang tidak memiliki pengaruh di masyarakat memperbesar peluang kecenderungan untuk menjadikan anak (suami) selalu miskin daripada tidak pernah miskin sebesar 118,758 kali lipat dibandingkan orang tua yang memiliki pengaruh di masyarakat. Berdasarkan kajian pada keluarga generasi II, hasil penelitian menunjukkan bahwa faktor yang memengaruhi dinamika kemiskinan suami adalah pendidikan suami $(\alpha<0,05)$ dan strategi rekayasa sumber nafkah yang dilakukan keluarga generasi II $(\alpha<0,10)$. Peningkatan pendidikan yang ditempuh suami memperbesar peluang kecenderungan suami untuk tidak pernah miskin 1,376 kali lipat dari selalu miskin $(p<1)$. Hal ini menunjukkan semakin tinggi pendidikan suami maka peluang untuk tidak pernah miskin $(\operatorname{Exp}(B)=1,376)$ yang dimiliki suami lebih besar 
dibandingkan peluang selalu miskin $(\operatorname{Exp}(B)=0,727)$. Sementara itu, semakin banyak dan sering strategi rekayasa sumber nafkah yang dilakukan keluarga generasi II memperbesar peluang kecenderungan suami untuk tidak pernah miskin 1,043 kali lipat dari selalu miskin $(p<1)$. Semakin banyak dan sering strategi rekayasa sumber nafkah yang dilakukan keluarga generasi II maka peluang untuk tidak pernah miskin $(\operatorname{Exp}(B)=1,043)$ yang dimiliki suami lebih besar dibandingkan peluang selalu miskin $(\operatorname{Exp}(B)=0,959)$.

Hasil penelitian menunjukkan bahwa faktor pada keluarga generasi I yang berpengaruh terhadap dinamika kemiskinan istri adalah pendidikan ibu $(\alpha<0,01)$, kepemilikan Iahan pertanian $(\alpha<0,01)$, dan pengaruh orang tua di masyarakat $(\alpha<0,01)$. Kecenderungan ibu yang tidak memiliki kemampuan membaca, menulis, dan berhitung (calistung) untuk menjadikan anak (istri) selalu miskin daripada tidak pernah miskin sebesar 135,757 kali lipat dibandingkan ibu yang memiliki kemampuan calistung. Ketiadaan lahan pertanian orang tua memperbesar peluang kecenderungan anak (istri) untuk selalu miskin daripada tidak pernah miskin sebesar 1.462 kali lipat dibandingkan orang tua yang memiliki lahan pertanian. Sementara itu, kecenderungan orang tua yang tidak memiliki pengaruh di masyarakat untuk menjadikan anak (istri) selalu miskin daripada tidak pernah miskin sebesar 73,751 kali lipat dibandingkan orang tua yang memiliki pengaruh di masyarakat. Hal ini menunjukkan pendidikan ibu, kepemilikan lahan pertanian, dan pengaruh orang tua di masyarakat pada keluarga generasi I memiliki peran penting dalam mendorong anak untuk menjadi tidak pernah miskin.

Berdasarkan kajian pada keluarga generasi II, hasil menunjukkan bahwa faktor yang memengaruhi dinamika kemiskinan istri adalah pendidikan istri $(\alpha<0,05)$. Peningkatan pendidikan yang ditempuh istri memperbesar peluang kecenderungan istri untuk tidak pernah miskin sebesar 1,366 $(p<1)$. Hal ini menunjukkan semakin tinggi pendidikan istri, peluang untuk tidak pernah miskin $(\operatorname{Exp}(B)=1,366)$ lebih besar dibandingkan peluang selalu miskin $(\operatorname{Exp}(B)=0,732)$.

Tidak pernah miskin vs jatuh miskin. Hasil penelitian menunjukkan bahwa tidak terdapat faktor dari keluarga generasi I yang berpengaruh terhadap dinamika suami dan istri pada perbandingan dinamika tidak pernah miskin dan jatuh miskin. Berdasarkan kajian pada keluarga generasi II, hasil penelitian menunjukkan bahwa faktor yang memengaruhi dinamika kemiskinan suami adalah besar keluarga $(\alpha<0,05)$ dan strategi rekayasa sumber nafkah yang dilakukan keluarga generasi II $(\alpha<0,05)$. Semakin banyak jumlah anggota keluarga yang dimiliki keluarga generasi II, maka kecenderungan suami untuk jatuh miskin 1,634 kali lipat dari tidak pernah miskin ( $p>1)$. Hal ini menunjukkan semakin banyak jumlah anggota keluarga yang dimiliki keluarga generasi II maka peluang untuk jatuh miskin yang dimiliki suami lebih besar dibandingkan peluang tidak pernah miskin. Sementara itu, semakin banyak dan sering strategi rekayasa sumber nafkah yang dilakukan keluarga generasi II memperbesar peluang kecenderungan suami untuk tidak pernah miskin 1,037 kali lipat dari jatuh miskin $(p<1)$. Hal ini menunjukkan semakin banyak dan sering strategi rekayasa sumber nafkah yang dilakukan keluarga generasi II maka peluang untuk tidak pernah miskin $(\operatorname{Exp}(B)=1,037)$ yang dimiliki suami lebih besar dibandingkan peluang jatuh miskin $(\operatorname{Exp}(B)=0,964)$.

Hasil penelitian menunjukkan bahwa faktor dari keluarga generasi II yang memengaruhi dinamika kemiskinan istri adalah besar keluarga $(\alpha<0,05)$, pendidikan istri $(\alpha<0,10)$, dan strategi rekayasa sumber nafkah yang dilakukan keluarga generasi II $(\alpha<0,10)$. Semakin banyak jumlah anggota keluarga yang dimiliki keluarga generasi II, maka kecenderungan istri untuk jatuh miskin 1,837 kali lipat dari tidak pernah miskin $(p>1)$. Hal ini menunjukkan semakin banyak jumlah anggota keluarga yang dimiliki keluarga generasi II maka peluang untuk jatuh miskin yang dimiliki istri lebih besar dibandingkan peluang tidak pernah miskin. Peningkatan pendidikan yang ditempuh istri memperbesar peluang kecenderungan istri untuk tidak pernah miskin 1,297 kali lipat dari jatuh miskin $(p<1)$. Hal ini menunjukkan semakin tinggi pendidikan istri maka peluang untuk tidak pernah miskin $(\operatorname{Exp}(B)=1,297)$ yang dimiliki istri lebih besar dibandingkan peluang jatuh miskin $(\operatorname{Exp}(B)=0,771)$. Sementara itu, semakin banyak dan sering strategi rekayasa sumber nafkah yang dilakukan keluarga generasi II memperbesar peluang kecenderungan istri untuk tidak pernah miskin 1,036 kali lipat dari jatuh miskin $(p<1)$. Hal ini menunjukkan semakin banyak dan sering strategi rekayasa sumber nafkah yang dilakukan keluarga generasi II maka peluang untuk tidak pernah miskin $(\operatorname{Exp}(B)=1,036)$ yang dimiliki istri lebih besar dibandingkan peluang jatuh miskin $(\operatorname{Exp}(B)=0,965)$. 
Tidak pernah miskin vs keluar dari kemiskinan. Hasil penelitian menunjukkan bahwa faktor pada keluarga generasi I yang berpengaruh terhadap dinamika kemiskinan suami adalah pengaruh orang tua di masyarakat $(\alpha<0,01)$. Kecenderungan orang tua yang tidak memiliki pengaruh di masyarakat untuk menjadikan anak (suami) keluar dari kemiskinan daripada tidak pernah miskin sebesar 43,330 kali lipat dibandingkan orang tua yang memiliki pengaruh di masyarakat. Hal ini menunjukkan bahwa kepemilikan pengaruh orang tua di masyarakat memiliki peran penting dalam mendorong anak menjadi tidak pernah miskin. Berdasarkan kajian pada keluarga generasi II, tidak terdapat faktor yang berpengaruh terhadap dinamika kemiskinan suami.

Hasil penelitian menunjukkan bahwa faktor pada keluarga generasi I yang berpengaruh terhadap dinamika kemiskinan istri adalah pendidikan ibu $(\alpha<0,01)$, kepemilikan lahan pertanian $(\alpha<0,01)$, pengaruh orang tua di masyarakat $(\alpha<0,05)$. Kecenderungan ibu yang tidak memiliki kemampuan calistung untuk menjadikan anak (istri) keluar dari kemiskinan daripada tidak pernah miskin sebesar 170,915 kali lipat dibandingkan ibu yang memiliki kemampuan calistung. Ketiadaan lahan pertanian orang tua memperbesar peluang kecenderungan anak (istri) untuk keluar dari kemiskinan daripada tidak pernah miskin sebesar 219,358 kali lipat dibandingkan orang tua yang memiliki lahan pertanian. Sementara itu, kecenderungan orang tua yang tidak memiliki pengaruh di masyarakat untuk menjadikan anak (istri) keluar dari kemiskinan daripada tidak pernah miskin sebesar 9,887 kali lipat dibandingkan orang tua yang memiliki pengaruh di masyarakat. Hal ini menunjukkan pendidikan ibu, kepemilikan lahan pertanian, dan pengaruh orang tua di masyarakat pada keluarga generasi I memiliki peran penting dalam mendorong anak menjadi tidak pernah miskin.

Berdasarkan kajian pada keluarga generasi II, hasil penelitian menunjukkan bahwa faktor yang memengaruhi dinamika kemiskinan istri adalah strategi nafkah ganda $(\alpha<0,05)$. Semakin banyak dan sering strategi nafkah ganda yang dilakukan keluarga generasi II memperbesar peluang kecenderungan istri untuk tidak pernah miskin 1,032 kali lipat dari keluar dari kemiskinan $(p<1)$. Hal ini menunjukkan semakin banyak dan sering strategi nafkah ganda yang dilakukan keluarga generasi II maka peluang untuk tidak pernah miskin $(\operatorname{Exp}(B)=1,032)$ yang dimiliki istri lebih besar dibandingkan peluang keluar dari kemiskinan $(\operatorname{Exp}(B)=0,969)$.

\section{PEMBAHASAN}

Analisis dinamika kemiskinan menunjukkan bahwa dominasi dinamika kemiskinan di wilayah hulu berbeda dengan di wilayah hilir. Dinamika kemiskinan di wilayah hulu didominasi oleh kelompok tidak pernah miskin, sedangkan di wilayah hilir didominasi oleh kelompok selalu miskin. Berdasarkan penelitian Hartoyo et al. (2013), dominasi dinamika kemiskinan di wilayah hulu Cimanuk serupa dengan dinamika kemiskinan di perdesaan dan dinamika kemiskinan di wilayah hilir Cimanuk serupa dengan dinamika kemiskinan di perkotaan. Pola dinamika kemiskinan yang terjadi erat kaitannya dengan sumberdaya, akses, dan strategi nafkah keluarga. Berdasarkan pekerjaan, sebagian besar keluarga di wilayah hulu bekerja sebagai petani sayur. Petani dapat mengatur keamanan pangan keluarga dari hasil panen sehingga menghemat pengeluaran keluarga (Chirau et al., 2014). Petani di wilayah hulu biasa meragamkan jenis tanaman dan disesuaikan dengan iklim wilayah. Hal ini mendukung stabilitas produksi atau jika kuantitas produksi rendah, keluarga memiliki persediaan pangan untuk dikonsumsi sepanjang tahun. Sementara itu, keluarga di wilayah hilir yang bekerja di bidang pertanian menghadapi tantangan ketidakstabilan iklim, seperti musim kemarau yang panjang dan bencana banjir ketika musim hujan. Kondisi ini mengancam kerugian produksi, kekurangan bahan makanan, dan ketidakstabilan pendapatan (Kalinda \& Langyintuo, 2014). Berdasarkan bidang non-pertanian, keluarga miskin di wilayah hilir hanya mampu bekerja pada struktur terendah (buruh pabrik petasan atau kerupuk) atau usaha kecil seperti warung, tukang becak dan ojek dengan pendapatan tidak stabil. Temuan ini sejalan dengan penelitian Adepoju \& Oyewole (2014) yang menyatakan bahwa rumah tangga miskin yang berpendapatan tidak stabil paling tinggi berada pada rumah tangga non-pertanian. Hal ini menunjukkan bahwa dengan potensi wilayah berbasis pertanian, memanfaatkan pertanian akan lebih menstabilkan pendapatan.

Penelitian menemukan bahwa persentase kelompok yang jatuh miskin lebih banyak di wilayah hulu sedangkan kelompok yang keluar dari kemiskinan lebih banyak ditemukan di wilayah hilir. Keluarga di wilayah hulu memiliki ukuran keluarga yang lebih besar dan rata-rata pendidikan yang lebih rendah dibandingkan 
keluarga di wilayah hilir. Besar keluarga ditemukan memberikan peluang jatuh miskin yang lebih besar kepada suami dan istri dibandingkan peluang tidak pernah miskin. Kepemilikan anak tanpa diiringi investasi anak yang optimal, akan menciptakan tantangan yang lebih besar bagi anak untuk menghadapi perkembangan global. Sebagian keluarga di wilayah hulu beranggapan bahwa kurang pentingnya pendidikan bagi anak-anak mereka. Mereka memiliki sudut pandang bahwa anak mereka akan menjadi petani seperti mereka yang tidak membutuhkan pendidikan tinggi. Sudut pandang yang turunmenurun ini memberikan dampak kerentanan nafkah ketika terjadi transformasi agraria. Dampak transformasi agraria dapat berupa ketimpangan penguasaan sumber-sumber nafkah dan hilangnya berbagai sumber nafkah tradisi yang diikuti struktur nafkah baru (nonpertanian) (Dharmawan, 2007). Penelitian menemukan bahwa pendidikan memberikan peluang tidak pernah miskin yang lebih besar kepada suami dan istri dibandingkan peluang selalu miskin. Hal ini sejalan dengan penelitian Surachman \& Hartoyo (2015). Pakpahan et al. (2009) menemukan bahwa pendidikan memiliki pengaruh terhadap transfer kemiskinan antargenerasi. Pendidikan memiliki peran penting dalam menentukan jenis perkerjaan dan meningkatkan pendapatan seseorang (Ali \& Najid 2013; lbekwe, et al., 2010; Simanjuntak et al., 2010). Penelitian menemukan bahwa pendidikan istri memberikan peluang tidak pernah miskin yang lebih besar dibandingkan peluang jatuh miskin. Perempuan dengan pendidikan yang baik memiliki kesempatan pekerjaan yang lebih baik dan dapat membantu meningkatkan pendapatan keluarga.

Strategi nafkah merupakan aktivitas yang dilakukan untuk bertahan hidup melalui pengembangan sumberdaya keluarga untuk mencapai kesejahteraan yang berkelanjutan (Scoones, 2009). Penelitian menunjukkan bahwa semakin banyak dan sering strategi rekayasa sumber nafkah akan meningkatkan peluang tidak pernah miskin dibandingkan peluang selalu miskin dan jatuh miskin. Puspitawati et al. (2008) menemukan bahwa keluarga miskin bekerja lembur (penambahan sumber waktu) untuk meningkatkan pendapatan. Terdapat perbedaan yang nyata pada strategi rekayasa sumber nafkah yang dilakukan keluarga miskin dan keluarga tidak miskin di wilayah hulu $(p<0,01)$. Keluarga yang tidak miskin melakukan strategi rekayasa sumber nafkah yang lebih banyak dibandingkan keluarga yang miskin di wilayah hulu. Hal ini membuktikan hipotesis dan penelitian terdahulu bahwa keluarga miskin dengan pendidikan yang rendah tidak memiliki banyak strategi untuk bertahan hidup dibandingkan keluarga yang tidak miskin dan atau yang memiliki pendidikan tinggi.

Strategi nafkah ganda terbukti memberikan peluang keluar dari kemiskinan yang lebih besar dibandingkan peluang tidak pernah miskin. Penelitian menemukan bahwa strategi nafkah ganda lebih banyak dimiliki oleh keluarga di wilayah hilir dibandingkan keluarga di wilayah hulu. Analisis ini memperkuat temuan persentase dinamika keluar dari kemiskinan yang lebih tinggi di wilayah hilir dibandingkan di wilayah hulu. Selain itu, perbedaan yang nyata ditemukan pada strategi rekayasa spasial dimana rata-rata indeks di wilayah hilir lebih tinggi dibandingkan di wilayah hulu. Penelitian Mukli \& Mersini (2013) menemukan bahwa migrasi merupakan faktor yang signifikan meningkatkan pendapatan. Aktivitas nafkah dipengaruhi oleh lama pendidikan (lbekwe, et al. 2010; Osarfo et al., 2016). Berdasarkan modal manusia, tingkat pendidikan yang lebih tinggi mendukung lebih banyaknya alternatif bagi keluarga di wilayah hilir. Temuan ini memperkuat penelitian terdahulu yang membuktikan bahwa pendidikan mendorong mobilitas ekonomi ke atas dan memutus kemiskinan (Dartanto \& Nurkholis, 2012; Janjua \& Kamal, 2011; Surachman \& Hartoyo, 2012). Miskinnya infrastruktur dan rendahnya akses merupakan penyebab kemiskinan (Kalinda, 2014; Korankye, 2014). Terbukanya akses dan kesempatan merupakan faktor penting dalam pengembangan pola nafkah (Lienert \& Burger, 2015). Berdasarkan modal lingkungan-alam, akses yang lebih terbuka di wilayah hilir mendorong lebih banyaknya pasar kerja yang dapat dijangkau oleh keluarga.

\section{SIMPULAN DAN SARAN}

Keberhasilan strategi nafkah merupakan proses panjang yang menjembatani sejarah dan masa depan kesejahteraan. Proses ini dimulai dari transfer modal keluarga generasi I kepada keluarga generasi II, serta berlanjut pada pengembangan modal dan pemanfaatan akses keluarga generasi II untuk mencapai outcome, yakni peningkatan kesejahteraan. Proses investasi anak seperti penyediaan fasilitas pendidikan oleh keluarga generasi I akan menentukan strategi nafkah yang dapat dilakukan anak pada keluarga generasi II. Selain itu, keterbukaan akses dan kesempatan memiliki peran penting dalam menentukan 
aktivitas nafkah keluarga. Penelitian membuktikan bahwa strategi nafkah memengaruhi dinamika kemiskinan keluarga di wilayah hulu dan hilir DAS Cimanuk. Rendahnya pendidikan dan keterbatasan akses serta kesempatan masih menjadi tantangan pengentasan kemiskinan.

Berdasarkan simpulan di atas, rekomendasi yang diberikan adalah pemerintah perlu lebih mengoptimalkan program pencegahan dan pengentasan kemiskinan yang telah ada. Program usaha berbasis potensi lokal perlu digalakkan dengan melibatkan peran pemerintah lokal, akademisi, investor dan pengusaha yang ahli di bidangnya. Karakteristik lokasi dalam penelitian ini menjadi keterbatasan penelitian karena merepresentasikan kemiskinan di Indonesia tidak cukup hanya mengkaji satu jenis karakteristik wilayah. Penelitian selanjutnya diharapkan melakukan kajian dinamika kemiskinan di wilayah dengan karakteristik berbeda. Alat ukur kesejahteraan keluarga generasi I masih bersifat umum dan menggunakan narasumber keluarga generasi II. Hal ini memungkinkan adanya bias mengenai informasi keluarga generasi I. qePenelitian selanjutnya diharapkan melakukan pengembangan instrumen status kemiskinan keluarga asal. Selain itu, kajian pengaruh kesejahteraan lansia terhadap dinamika kemiskinan antargenerasi menarik dikaji untuk melihat peran antargenerasi.

\section{DAFTAR PUSTAKA}

Adepoju, A. O., \& Oyewole, O. O. (2014). Rural livelihood diversivication and income inequelity in local government area Akinyele, Ibadan, Oyo State, Nigeria. Journal of Agricultural Sciences, 59(2), 175-186.

Ali, S., \& Ahmad, N. (2013). Human capital and poverty in Pakistan: Evidence from the Punjab Province. European Journal of Science and Public Policy, 11.

[Badan Pusat Statistik]. (2015). Angka kemiskinan di Indonesia. Diakses pada: bps.go.id

[Bank Dunia]. (2013). Mengukur Kerentanan terhadap Kemiskinan. Presentasi disampaikan pada Forum Kebijakan Publik Asia, Mei 2013. Diakses pada: https://www.tnp2k.go.id

Becker, G. S. 1993. Human Capital: A Theoretical and Empirical Analysis, with Special Reference to Education. Third
Edition. Chicago and London: The University of Chicago Press.

Bottema, T., Masdjidin, S., \& Madiadipura, H. (2009). Family life history as a tool in the study of long-term dynamics of poferty : an exploration. Di dalam : Rusastra, Pasaribu, Yusdja Y, editor. Land and Household economy 1970-2005. Bogor (ID) : Indonesian Center for Agriculture Socio-Economic and Policy Studies

Chirau, T. J., Nkambule, S., \& Mupambwa, G. (2014). Rural livelihoods in Zimbabwe: heterogeneity, diversification and vulnerability. International Journal of Innovation and Applied Studies, 5(1), 515

Dharmawan, A. H. (2007). Sistem penghidupan dan nafkah pedesaan: Pandangan sosiologi nafkah (livelihood Sosiology) mazhab Barat dan mazhab Bogor. Solidarity: Jurnal Transdisiplin Sosiologi, Komunikasi, dan Ekologi Manusia, 1.

Dartanto, T., \& Nurkholis. (2012). Finding out the determinants of poverty dynamics in indonesia: evidence from data panel. Bulletin of Indonesian Economic Studies. Diambil dari http://mpra.ub.unimuenchen.de/41185/

Hartoyo, Herawati, T., \& Djamaluddin, M. D. (2013). Transfer kemiskinan antar generasi di wilayah agroekologi yang berbeda: perdesaan dan perkotaan. Prosiding Seminar Hasil-Hasil PPM IPB 2013, 11, 682-697.

Ibekwe, U. C., Eze, C. C., Ohajianya, D. O., Orebiyi, J. S., Onyemauwa, C. S., \& Korie, O. C. (2010). Determinants of non-farm income among farm households in south east Nigeria. Researcher, 2(7), 49-52.

Ibekwe, U. C., Eze, C. C., Onyemauwa, C. S., Henri-Ukoha, A., Korie, O. C. \& Nwaiwu, L.U. (2010). Determinants of farm and off-farm income among farm households in south east Nigeria. Academia Arena, 2(10), 58-61.

Janjua, P. Z., \& Kamal, U. A. (2011). The role of education and income in poverty alleviation: a cross-country analysis. The Lahore Journal of Economics, 16(1),143172.

Kalinda, T. (2014). Multiple Shocks and risk management strategies among rural household in Zambia's mazabuka 
district. Journal of Sustainable Development, 7(5).

Kalinda, T., \& Langyintuo, A. (2014). Livelihood strategies, shocks and coping mechanisms among rural households in Southern Zambia. Current Research Journal of Social Sciences, 6(4), 120133.

[KLH] Kementerian Lingkungan Hidup. (2012). DAS Cimanuk [internet]. [Diunduh pada 2015 Maret 10]. Diambil dari http://ppejawa.com/ekoregion/dascimanuk/.

Korankye, A. (2014). Causes of poverty in Africa: A review of literature. American International Journal of Social Science, 3(7).

Lienert, J., \& Burger. (2015). Merging capabilities and livelihoods: analyzing the use of biological resources to improve well-being. Ecology and Society, 20(2), $20 . \quad$ Doi: http://dx.doi.org/10.5751/ES-07405200220

Magnuson, K., \& Votruba-Drzal, E. (2009). Enduring influences of childhood. Focus, 26(2).

Morse, S., \& McNamara, N. (2013). Sustainable livelihood approach. Springer.

Mukli, L., \& Mersini, R. (2013). An empirical study of factors affecting poverty level among Albanian families. Mediterranean Journal of Social Sciences, 4(11), 646649. Doi: $10.5901 / \mathrm{mjss} .2013 . v 4 n 11 p 646$

Osarfo, D., Senadza, B., \& Amponsah, E. N. (2016). The Impact of non-farm activities on rural farm household income and food security in the upper east and upper west regions of Ghana. Theotical Economics Letter, 6, 388-400. Diambil dari http://www.scirp.org/journal/tel

Pakpahan, Y. M., Suryadarma, D., \& Suryahadi, A. (2009). Destined poverty persistence in Indonesia.. SMERU Research Institute, Working Paper.

Puspitawati, H., Herawati, T., \& Sarma, M. (2008). Dampak Subsidi Langsung Tunai (SLT)-BBM pada kesejahteraan keluarga miskin di Bogor, Jawa Barat. Jurnal IImu Keluarga dan Konsumen, 1(1).

Scoones, I. (1998). Sustainable rural livelihoods: a framework for analisis. IDS Working Paper 72.

Scoones, I. (2009). Livelihoods perspectives and rural development. Journal of Peasant Studies, 36(1).

Simanjuntak, M., Puspitawati, H., \& Djamaluddin, M. D. (2010). Karakteristik demografi, sosial, dan ekonomi keluarga penerima Program Keluarga Harapan (PKH). Jurnal IImu Keluarga dan Konsumen, 3(2), 101 - 113.

Surachman, A., \& Hartoyo. (2012). Born to be destitude: capital transfer and intergenerational transfer of poverty. Undergraduate Research Journal for Human Sciences, 11. Diambil dari: http://www.kon.org/urc/v11/surachman.ht $\mathrm{ml}$

Surachman, A., \& Hartoyo. (2015). Parental Investment and Poverty Dynamics in West Java, Indonesia. Journal of Family and Economic Issues, Springer. 36(2). 